\title{
VOTING AS A POSITIVE RIGHT: A REPLY TO FLANDERS
}

\author{
JOSEPH FISHKIN*
}

Chad Flanders' thoughtful article ${ }^{1}$ demonstrates that the Murkowski litigation raised questions with surprisingly fundamental implications for election law. This brief response addresses just one of those questions. The question, which at first blush sounds awfully narrow and wonkish, is this: Can a state allow write-in votes, but discourage them by making them difficult to cast?2 I will argue that the answer is no-for reasons that highlight two fundamental, but underappreciated, aspects of election law.

I.

The Supreme Court has settled the question of whether states must allow write-in candidacies and votes at all: They need not. In Burdick $v$. Takushi, ${ }^{3}$ the Court upheld a Hawaiian statutory scheme that prohibited write-in votes entirely. 4 The scheme did offer minor party and independent candidates what the Court deemed "easy access to the ballot." 5 In the Court's view, "the function of the election process" itself is to narrow the list of candidates and find a winner; the state's interest

* Assistant Professor, University of Texas School of Law. I would like to thank Chad Flanders, Willy Forbath, Cary Franklin, and Heather Gerken for helpful comments.

1. Chad Flanders, How do you spell M-U-R-K-O-W-S-K-I? Part I: The Question of Assistance to the Voter, 28 ALASKA L. REV. 1 (2011).

2. Id. at 21-25; see id. at 3-4 ("[T]o what extent can a state legitimately disadvantage a write-in candidate who has won neither party's primary? Can a state, for reasons of either principle or expediency, make it harder for voters to write-in the names of candidates?").

3. 504 U.S. 428 (1992).

4. Id. at 441 .

5. Id. at 436. Specifically, Hawaii allowed independent candidates to run in a "nonpartisan primary" and proceed to the general election if they received ten percent of the primary votes, or a number sufficient to nominate a party candidate. $I d$. Alternatively, new parties, including those organized around one candidate, could secure a spot on the general election ballot through a petition signed by one percent of the state's registered voters. $I d$. at 435 . Of course, this is hardly "easy" in comparison to Alaska's standards for write-in candidates, who need only file a letter of intent at least five days before the election. See ALASKA STAT. § 15.25 .105 (2010). 
in "winnowing out candidates" and "avoiding divisive sore-loser candidacies" was sufficiently weighty to justify an outright prohibition of write-in candidacies and votes. ${ }^{6}$

Since a state may choose either to allow or to prohibit write-in votes, common sense might suggest that an in-between position of "permit but discourage" is equally constitutional: allow write-in votes, but discourage them by making them a bit more difficult to cast. The Alaska Republican Party argued in the Murkowski litigation that not only could a state do this, Alaska was doing it, by enacting stringent rules that write-in votes must be correctly spelled. ${ }^{7}$ The argument was that such rules make write-in votes more difficult to cast and thereby function as part of a larger scheme aimed at discouraging write-ins and encouraging voters instead to choose one of the candidates on the ballot. 8

The claim that a state can "permit but discourage" is appealing on its face. After all, reasons sufficient to justify an outright ban on something are almost always also sufficient to justify regulations short of an outright ban. Supposing that the reasons the Court laid out in Burdick justify a regime of no write-ins at all, one would think those same reasons could also justify more modest measures aimed at pushing voters to "focus" on the listed candidates. ${ }^{9}$

What this straightforward argument misses is that states are doing more than one thing when they regulate elections. Election law defines the structure of democratic competition: the rules that determine the choices voters face and the terms on which voters make those choices. When a state draws a new map of legislative districts, enacts a sore loser law, or decides whether and on what terms to allow write-in candidacies, it is defining the terms of democratic competition. The players here are candidates and parties. The structural rules affect which of those players will win elections. Thus, such rules are typically the

6. Id. at 438-40. The Court also cited an interest in preventing "party raiding." Id. at 439. Scholars have roundly criticized these interests. See, e.g., Samuel Issacharoff \& Richard H. Pildes, Politics As Markets: Partisan Lockups of the Democratic Process, 50 STAN. L. REV. 643, 668-674 (1998) (arguing that the real purpose and effect of the regulation, which the court failed to understand, was to entrench the power of a ruling faction within a party and prevent internal defection).

7. Flanders, supra note 1 , at 24.

8. Id. (citing Alaska Republican Party's Opposition to Petition for Review at 8-10, State, Div. of Elections v. Alaska Democratic Party, No. S-14054 (Alaska Oct. 29, 2010)).

9. See Burdick, 504 U.S. at 439 (holding that Hawaii's rule focuses the attention of voters). 
object of intense interest, lobbying, legislation, and litigation by parties and candidates and their allies.

Election law also does something else: it determines which individuals will be allowed to vote and which votes, once cast, will count. When a state adopts rules about what forms of identification are required to vote, or rules about which imperfectly-filled-out ballots will be counted, the state is doing more than simply defining the terms of the competition among candidates and parties. It is also making decisions that affect the interests of individual voters, deciding what burdens voters will face when they attempt to exercise their right to vote. Wholly apart from structural questions about the rules of the competition, and from questions about which faction's ox may be gored, each individual voter has an interest in being able to cast a ballot and have it counted. ${ }^{10}$

Rules that make write-in votes difficult to cast may create a trap for the unwary: fill out the form incorrectly, and risk being disenfranchised. In this way, the "permit but discourage" regime discussed above does something quite different from either allowing write-ins or prohibiting them. We miss this point if we limit our analysis exclusively to the structural question of how open or closed a given electoral system is to write-in candidacies. On that dimension, "permit but discourage" is indeed a middle point between "allow" and "prohibit." But that question, while important, is not the only one in play.

When a state decides either to allow or to prohibit write-ins, no one is disenfranchised. To be sure, voting is, to a limited extent, a form of expression; a write-in ban affects voters' First Amendment interests. ${ }^{11}$ But from the perspective of an individual voter, a write-in ban is not the same as being prevented from voting or having one's vote discarded. The experience of walking into the voting booth and not seeing one's preferred choice-or not seeing any choices that one likes-is not disenfranchisement. Indeed, in the age of negative advertising, it may be the usual experience of the typical American voter.

Courts can see the difference between a write-in ban like the one in Burdick, which channels choices but disenfranchises no one, and a rule that actually imperils some voters' right to cast a ballot and have it counted. Courts will scrutinize the latter rule more closely, for reasons that are rooted in a commitment to the equal citizenship of each

10. In a forthcoming article, I offer a fuller argument for making this distinction. Joseph Fishkin, Equal Citizenship and the Individual Right to Vote, 86 IND. L.J. (forthcoming 2011), available at http://papers.ssrn.com/sol3/ papers.cfm?abstract_id $=1742642$.

11. This was central to the interest the Court considered in Burdick. 504 U.S. at 430; see also Adam Winkler, Note, Expressive Voting, 68 N.Y.U. L. REV. 330 (1993). 
individual voter. ${ }^{12}$ Heightened scrutiny is particularly appropriate here because this trap for the unwary is likely to have a disproportionate effect on some of the sorts of voters whose status as full, equal citizens with the right to cast a ballot may already be relatively tenuous: citizens who are relatively less educated, who are very elderly, who have disabilities that make the mechanical aspects of casting the ballot tricky, and so forth. ${ }^{13}$ The structural aims that were sufficient to uphold the rule in Burdick ${ }^{14}$ are unlikely to be strong enough to justify a rule that places such a burden on voters' participation rights. Courts should, and likely would, conclude that a state cannot "permit but discourage" write-in votes in the manner suggested by the Alaska Republican Party. ${ }^{15}$

The logic here does not depend on any claim that disfavoring write-in candidates relative to candidates listed on the ballot is constitutionally problematic. Indeed, write-in status is inherently disfavored. That is, the state already steers voters toward the listed candidates by listing them on the ballot. Furthermore, nothing is stopping states from channeling voters' choices in a more decisive way by banning write-ins altogether. The constitutional problem arises because the state is discarding votes, thereby placing a burden on some voters' ability to be counted as full and equal citizens. If a state required all voters to write down their choices and spell them correctly, on pain of having their votes discarded, this problem would be worse, not better.

But now we are at the edge of a deeper and more interesting problem. Against what baseline does one measure a "burden"? Alaska had a relatively easy solution to the problem of throwing out votes unnecessarily: rely on an intent-of-the-voter standard rather than demanding that votes be spelled correctly. Still, under Alaska's standard, and under any plausible standard, it is necessary to discard votes whose intent is genuinely unclear. These unclear votes and other failed votes do not appear out of the ether. They are the product of interactions, most of them fairly predictable, between the voter and the rules and technological apparatus provided by the state. For example, requiring voters to signal their preferred candidate's name letter by letter, scrolling through the entire alphabet for each letter using an awkward rotary dial, is likely to result in more errors and incoherence

12. See Fishkin, supra note 10 (manuscript at 36-39).

13. Id. (manuscript at 51-53).

14. See 504 U.S. at $439-40$.

15. In the Murkowski litigation, the Alaska Supreme Court avoided this issue because it rejected the Republican Party's reading of the statute on other grounds. See Flanders, supra note 1, at 24-25. 
than simply allowing voters to write a name on a piece of paper. ${ }^{16}$ Refusing to help voters operate the machine would further compound the problem, as would refusing to furnish voters with information about how to spell candidates' names. But if the state's refusal to do these things creates a burden on the right to vote, what or how much must a state do to avoid creating such a burden?

This problem arises for a simple reason. Voters need help to vote. I do not mean that only a few voters or certain groups of voters need help. State action is required if any of us are to vote at all. The state must set up polling places, train workers, buy machines, print ballots. The entire enterprise of voting requires positive action by the state. This is because voting is, inescapably, a positive right.

\section{II}

It is a truism that "the Constitution is a charter of negative rather than positive liberties."17 This truism is mostly true. Although the distinction between positive and negative rights is not always so sharp, ${ }^{18}$ and most negative rights entail an apparatus of state enforcement, ${ }^{19}$ our courts have generally read the rights language of the United States Constitution to speak in negative rather than positive terms, that is, to speak in terms of what the state may not do to us. ${ }^{20}$

It is possible to try to frame the right to vote that way. Our law once did so. Before the emergence of the modern, universal right of

16. This ill-conceived method gained national prominence when voters in Tom DeLay's former district found themselves using it to tap out the name of the Republican candidate to succeed him on a Hart InterCivic machine. See Byron York, In Texas, S-H-E-L-L-E-Y S-E-K-U-L-A G-I-B-B-S Has a Real Chance to Win, NATIONAL REVIEW ONLINE (Nov. 3, 2006) http:/ / www.nationalreview.com/ articles / 219154/texas-s-h-e-l-l-e-y-s-e-k-u-l-g-i-b-b-s-has-real-chance-win/ byron-york (describing the voting method).

17. Jackson v. City of Joliet, 715 F.2d 1200, 1203 (7th Cir. 1983) (Posner, J.).

18. For example, the right not to be deprived of liberty without due process of law sounds self-evidently negative, but it translates into a positive right to adequate legal representation when charged with a crime. See Gideon v. Wainwright, 372 U.S. 335, 339-45 (1963) (incorporating the Sixth Amendment right to counsel against the states through the Fourteenth Amendment).

19. See Stephen Holmes \& CASS Sunstein, THE COST OF Rights (1999) (arguing that this fact renders problematic the distinction between negative and positive rights).

20. Judge Posner's formulation is typical: "The men who wrote the Bill of Rights were not concerned that government might do too little for the people but that it might do too much to them." Jackson, 715 F.2d at 1203; see Frank B. Cross, The Error of Positive Rights, 48 UCLA L. REV. 857 (2001). 
citizens to vote, ${ }^{21}$ a succession of constitutional amendments and court decisions constructed a series of narrower, more negatively phrased constitutional rights not to be denied the right to vote on specific grounds such as race, ${ }^{22} \operatorname{sex}^{23}$ failure to pay a poll tax,$^{24}$ age, ${ }^{25}$ lack of ownership of property, ${ }^{26}$ and so on. These specific protections proliferated at an accelerating pace in the late 1960s and early 1970s, leading finally to the Court's recognition of a positive right to vote for each adult citizen untethered from these negative rights against specific forms of vote denial. ${ }^{27}$

But in truth, voting was a positive right (for those who had it) from the very start. Without positive state action, there is no voting. One way to define negative rights is to ask what rights would be automatically fulfilled if the state did nothing-or indeed, if the state did not exist. ${ }^{28}$ Although the limitations of this sort of thought experiment illustrate the conceptual difficulty of truly disentangling positive from negative rights, it does make clear that to the degree that any such distinction can

21. See Fishkin, supra note 10 (manuscript at 41-46). This right is not completely universal. Although the Court often states that voting can now be limited only by age, citizenship, and residency, this formulation ignores states' continuing disenfranchisement of felons and ex-felons. Id. (manuscript at 49-50).

22. U.S. CONST. amend. XV, \& 1 ("The right of citizens of the United States to vote shall not be denied or abridged by the United States or by any state on account of race, color, or previous condition of servitude.").

23. U. S. CONST. amend. XIX, § 1 ("The right of citizens of the United States to vote shall not be denied or abridged by the United States or by any state on account of sex.").

24. U.S. CONST. amend. XXIV, § 1 ("The right of citizens of the United States to vote in any primary or other election for President or Vice President, for electors for President or Vice President, or for Senator or Representative in Congress, shall not be denied or abridged by the United States or any state by reason of failure to pay any poll tax or other tax."); Harper v. Va. Bd. of Elections, 383 U.S. 663, 670 (1966).

25. For those at least eighteen. U. S. CONST. amend. XXVI, § 1 ("The right of citizens of the United States, who are 18 years of age or older, to vote, shall not be denied or abridged by the United States or any state on account of age.")

26. City of Phoenix v. Kolodziejski, 399 U.S. 204, 204 (1970); Cipriano v. Houma, 395 U.S. 701, 705-06 (1969).

27. See Dunn v. Blumstein, 405 U.S. 330, 336 (1972) ("In decision after decision, this Court has made clear that a citizen has a constitutionally protected right to participate in elections on an equal basis with other citizens in the jurisdiction."); see supra note 21. The right to vote on an equal basis with other citizens - or more generally, to be treated as the equal of one's fellow citizens in the democratic sphere-sounds in both liberty and equality, making it what some scholars now term a "dignity" claim. E.g., Jeremy Waldron, Dignity and Rank, 48 Eur. J. Soc. 201 (2007); Kenji Yoshino, The New Equal Protection, 124 HARV. L. REV. 747 (2011); see Fishkin, supra note 10 (manuscript at 37-39).

28. Cross, supra note 20, at 866 ("I propose the following simple test for distinguishing between positive and negative rights-if there was no government in existence, would the right be automatically fulfilled?"). 
be drawn, the right to vote is on the positive side of the line. Not only would there be no way to vote in the absence of government, there would also be no point.

The existence of an unambiguously positive right at the center of our scheme of federal constitutional rights raises a number of significant issues. For one thing, because the right to vote is linked with other rights in ways that courts cannot help but recognize, the positive character of the right to vote puts pressure on the Court's unwillingness to read the federal Constitution as a charter of positive rights in other spheres. In San Antonio v. Rodriguez, ${ }^{29}$ the Court had to struggle mightily to prevent the right to vote from becoming a basis for a positive right to education. ${ }^{30}$ The Court first blocked the connection by holding that a right to vote did not entail any right to make "the most informed electoral choice." 31 But logically, the Court had to concede that if some education was required to enable citizens to "participat[e] in the political process" at all, that minimal level or "identifiable quantum" of education would indeed be constitutionally guaranteed as a positive right. 32 The Court avoided this problem by asserting that there was "no indication" Texas fell below such a minimum. ${ }^{33}$ Had the suit in Rodriguez been framed in terms of educational adequacy rather than equity, as Frank Michelman argued that positive social rights claims are best framed, ${ }^{34}$ the implications for education of a positive right to vote would not have been so easily avoided. And indeed, state courts have used the connection between voting and education to decide how much state action is required to fulfill state constitutional rights to education. ${ }^{35}$

The positive character of the right to vote raises profound questions about the law of election administration itself. These are questions of a somewhat uncomfortable kind in the American constitutional tradition-questions about how much and what kinds of state action this positive right entails. Does the right to vote require assistance from

29. 411 U.S. 1 (1973).

30. See id. at 35-37.

31. Id. at 36 .

32. Id. at $36-37$

33. Id. at 37 (" $[\mathrm{N}]$ o charge fairly could be made that the system fails to provide each child with an opportunity to acquire the basic minimal skills necessary for the enjoyment of the rights of speech and of full participation in the political process.").

34. Frank I. Michelman, The Supreme Court, 1968 Term-Foreword: On Protecting the Poor Through the Fourteenth Amendment, 83 HARV. L. REV. 7, 9 (1969).

35. See Campaign for Fiscal Equity, Inc. v. New York, 655 N.E.2d 661, 666 (1995) (" $[\mathrm{A}]$ sound basic education . . . should consist of the basic literacy, calculating, and verbal skills necessary to enable children to eventually function productively as civic participants capable of voting and serving on a jury."). 
poll workers of the kind that was at issue in the Murkowski litigation - a list of names and how to spell them on request?36 What about help with operating the machine itself? As Flanders notes, one constraint on assistance of this kind is the need to avoid allowing poll workers, in the guise of assisting voters, to persuade, or worse, to coerce. ${ }^{37}$

In a similar vein, we might ask whether and to what extent accommodations for voters with disabilities, or ballots for voters who cannot read English, are constitutionally required. Both of these are forms of assistance required by statute. These statutes do constitutionally significant work by enabling voters who might otherwise be marginalized to cast ballots as equals of their fellow citizens. But these statutes apply only in certain circumstances. In the case of language assistance, the circumstances turn on the size of the group: the Voting Rights Act's language assistance provisions apply only to groups that are numerically large. ${ }^{38}$ In contrast, federal and state laws establish criteria for accommodating voters with disabilities that do not vary with the number of voters with disabilities in a given jurisdiction. ${ }^{39}$

It requires some work to understand why the scope of a positive individual right would change with the size of a group, let alone why it would do so for language and not for disability. The best answer seems to be that while the individual right does not change, any analysis of what the state must do to vindicate that right must take costs into

36. See Flanders, supra note 1 , at 5-7.

37. Id. at 10 .

38. See Voting Rights Act § 203, 42 U.S.C. § 1973aa-1a (2006) (triggering language assistance provisions when a single language minority accounts for more than 10,000 voting-age citizens, more than $5 \%$ of the citizen voting-age population in a jurisdiction, or more than $5 \%$ of the American Indian or Native Alaskan population on a reservation, and in addition, the illiteracy rate of citizens in this language minority is higher than the national illiteracy rate). Similarly, some state laws that go beyond federal law and that dispense with the illiteracy criterion also rely on numerical thresholds. See, e.g., CAL. ELEC. CODE $\S$ 2103 (West 2003) (requiring counties to provide certain forms of assistance, such as "mak[ing] reasonable efforts to recruit deputy registrars who are fluent" in that language, when a group of non-English speaking citizens "approximate 3 percent or more of the voting age residents of a precinct.").

39. The relevant federal statutes include provisions of the Voting Rights Act, 42 U.S.C § 1973aa-6 (2006), the Voting Accessibility for the Elderly and Handicapped Act (VAEHA), id. §§ 1973ee to 1973ee-6, Title II of the Americans with Disabilities Act, id. § 12132, and the Help America Vote Act, id. §§ 15301 to 15306. See also GAO, VOTERS WITH DisABILITIES: AcCESS TO POLLING PLACES AND Alternative Voting Methods 5 (2001) ("All states have provisions (in the form of statutes, regulations, or policies) that specifically address voting by people with disabilities."). No federal or state law of which I am aware turns on the number or proportion of voters with disabilities in a particular jurisdiction. 
account. At some point, a judge, legislature, or administrative agency must make a determination that this much, and no more, is required of the state, even though more might help some particular voter cast a ballot. Requiring uniform disability accommodations, but only printing ballots for the largest language minorities, is a compromise that reflects these countervailing cost considerations. It is also a compromise that may reflect some shadow conception of group rights and political power. Voting has a group dimension, in addition to its individual and structural elements, and groups the size of large language minorities have the ability to sway election outcomes in a way that other groups do not. Thus, part of the difference between language and disability may be that the law views language minority groups as making out group claims for representation that augment the individual accommodation claims of their members - or at least give the state a reason for choosing those claims, if it would be too costly to accommodate all claims. ${ }^{40}$

Once we start down the road of acknowledging that voting is a positive right that the state will have to spend money to vindicate, it is tempting to throw up our hands. How are courts or legislators to determine what this right entails? The temptation is to fall back on a model of equity rather than minimum provision, to hold that it doesn't matter what the state offers in the way of voting, as long as the rules are applied evenhandedly so that the voting process, however difficult or cumbersome, is open to all on equal terms. But this will not do. As Michelman argued a generation ago with regard to minimal social provision, minima are actually more justiciable than are equality claims when we are talking about positive rights. ${ }^{41}$ The project of deciding whether an election is open to all on equal terms is impossible: because some of us have disabilities, others do not speak English, and all of us live in different locations, work different hours, and so forth, many perfectly neutral and uniformly applied rules that vindicate my right to vote may thwart yours. Instead, the best way is the one that seems the most foreign, but actually is not: Just as federal courts decide how much and what kind of criminal representation meets a threshold of adequacy, and just as state courts determine what forms of education their constitution requires, legislatures and courts must decide how much and what kinds of assistance the positive right to vote requires, taking into account the different circumstances voters face. The answers will

40. Numerous states and localities have passed laws specifically requiring that ballots or other materials be made available in particular languages. See Angelo N. Ancheta, Language Assistance and Local Voting Rights Law, 44 IND. L. REV. 161 (2010). These laws reflect political compromises among groups.

41. Michelman, supra note 34, at 9-11. 
evolve over time, as our experience of the election process evolves. The Alaska Supreme Court has advanced the ball a small but perceptible amount by judging that, yes, the right to vote does include being informed of how to spell M-U-R-K-O-W-S-K-I. 